College of William \& Mary Law School William \& Mary Law School Scholarship Repository

1966

\title{
The First Amendment and the Suppression of Warmongering Propaganda in the United States: Comments and Footnotes
}

William W. Van Alstyne
William \& Mary Law School

Repository Citation

Van Alstyne, William W., "The First Amendment and the Suppression of Warmongering Propaganda in the United States: Comments and Footnotes" (1966). Faculty Publications. 783.

https://scholarship.law.wm.edu/facpubs/783

Copyright c 1966 by the authors. This article is brought to you by the William \& Mary Law School Scholarship Repository. https://scholarship.law.wm.edu/facpubs 


\title{
THE FIRST AMENDMENT AND THE SUPPRESSION OF WARMONGERING PROPAGANDA IN THE UNITED STATES: COMMENTS AND FOOTNOTES
}

\author{
WILLIAM W. VAN ALSTYNE*
}

\section{INTRODUCTION}

"Does the first amendment forbid the government to stop propaganda which may imperil the peace of the world?" This is the general and significant question which some of us were invited to try to answer in this symposium, and I earnestly regret that the question defies a plain, direct response. Nevertheless, I believe that a moment's consideration of the question itself will make it clear why a more piecemeal approach is unavoidable.

It is too hazardous to generalize about the relevance of freedom of speech under the first amendment to the international law of propaganda, not because the fellow who generalizes takes a risk of being a bigger fool only because he is willing to be wrong about a bigger question, but because "big" questions like this one lack meaning and clarity and so, inevitably, will the answer. The significance of the first amendment necessarily depends upon the context of its involvement. In the problem before us, there are simply too many unspecified variables to make a categorical "yes" or "no" equally responsive to all situations. For instance, what kind of propaganda which may imperil the peace are we talking about: warmongering, subversive, or defamatory? What is the source of the propaganda which we want to curtail: government agency, ranking government officer, or private citizen? In what way is the country associated with the propaganda: as the sender or the receiver? What kind of control are we contemplating: a treaty forbidding the government from broadcasting to foreign countries, a statute punishing inflammatory electioneering, a postal regulation cutting off propaganda from abroad? In what forum is the significance of the first amendment being considered: the International Court of Justice, a federal court, or the General Assembly of the United Nations?

Depending upon the particular arrangement of items, one selected from each of these incomplete and merely illustrative categories, we may come up with equally correct but opposite answers to the over-all question. If the United States were somehow before the International Court for having allegedly violated a treaty by its own systematic government broadcasts of defamatory propaganda into the country whose legitimate government objected, for instance, our own first amendment might well provide no defense whatever to the alleged treaty violation. On the other hand, if a candidate for President were brought before a federal court for having allegedly

- B.A. r955, University of Southern California; LL.B. 1958, Stanford University; Certificate, Hague Academy of International Law, 196I. Professor of Law, Duke University. 
violated a federal statute by exhorting a national audience to elect a man dedicated to victory through preventive war (the offense being that of engaging in "warmongering propaganda"), the first amendment would be his best defense.

So it is that the dramatic general question must be broken down into less dramatic parts for anyone to fashion a useful response. In their book on propaganda, Professors Whitton and Larson attempted this task and concluded that the first amendment really possesses a limited relevance of no great obstructive importance to propaganda controls. ${ }^{1}$ Professor Newhouse also noted the problematical relevance of the first amendment under certain circumstances, although he felt that at least in certain situations it would operate to block some kinds of propaganda control. ${ }^{2}$ In turn, I should like to examine three areas of national control over propaganda, to note certain critical distinctions within each area, and to offer some general reflections on the relationship between international law norms and the first amendment to our Constitution. The three areas are these: control by the government of its own propaganda; control by the government of propaganda originating abroad; control by the government of private propaganda originating within the United States. Like Professor Newhouse, I am laying to one side those cases in which the United States might somehow appear as a defendant in an international court, and I shall have nothing to say about the important question of the status of our Constitution in such a forum. Rather, the areas I shall be discussing are of concern only to the extent that our own efforts to control propaganda might raise questions before our own courts.

\section{I}

Control By the Government of Its Own Propaganda

In their earnest attempt to demonstrate the feasibility of controls over malevolent propaganda which may increase the peril of conventional war or nuclear annihilation, Professors Whitton and Larson led off with a very powerful statement: "The problem of freedom of speech in the constitutional sense simply does not arise when the government itself is doing the speaking." ${ }^{3}$ The statement was made to show that there could be no constitutional objection to self-imposed limitations restricting the government itself from engaging in warmongering, subversive, or defamatory propaganda. What Professors Whitton and Larson must have meant more specifically, however, was only that there may be no constitutional issue arising from a decision by our government itself to abstain from the systematic diffusion of tension-producing propaganda abroad, a statement which is probably correct. While such self-imposed

\footnotetext{
${ }^{1}$ John B. Whitton \& Arthur Larson, Propaganda: Towards Disarmament in the War of Words 24I-48 (1964) [hereinafter cited as Whrtron \& LARson]. See also id. at 233-40.

${ }^{2}$ Newhouse, The Constitution and International Agreements or Unilateral Action Curbing "PeaceImperiling" Propaganda, pp. 506-26 supra [hereinafter cited as Newhouse].

${ }^{3}$ Whitton \& Larson 242.
} 
restrictions pursuant to a given policy may be subject to change through constitutionally-protected political action affecting the policy itself, they would probably not be subject to successful court challenge by private citizens in the United States while they remained in effect.

At first, it might appear that self-imposed restrictions equally forbidding the government to generate warmongering propaganda at home would be equally free of constitutional objections, and to a considerable extent this is doubtless so: ${ }^{4}$ if the government elects to commit itself to a treaty to abstain from the systematic generation and distribution of its own warmongering propaganda at home, for instance, it is difficult to see how private citizens could secure standing in our courts and successfully claim a right on first amendment grounds to force the government to set up a domestic propaganda machine against its will.

With regard to formally-sponsored, government-generated propaganda directed to the nation at large, moreover, the first amendment may even be used to forbid it, rather than to protect it. Strange as it must sound in appraising an amendment which explicitly forbids abridging the freedom of speech, it is nonetheless arguable that the function of that amendment implicitly requires some silencing of the government itself. Private political discussion is protected from governmental abridgment primarily to restrain those in power at any given point in time from indefinitely perpetuating their own power and their own policies through the expedient of sup. pressing the utterance of ideas inimical to their own views. ${ }^{5}$ The danger of govern-

\footnotetext{
- But see pp. 537-40 infra, respecting an argument that the government is obliged to inform the people of the existence and content of foreign propaganda.

'Madison, in 4 AnNals of Cong. 934 (I794) [I793-1795] ("If we advert to the nature of Republican Government, we shall find that the censorial power is in the people over the Government, and not in the Government over the people."); Mills v. Alabama, 384 U.S. 214, 218-19 (1966):

"Whatever differences may exist about interpretations of the First Amendment, there is practically universal agreement that a major purpose of that Amendment was to protect the free discussion of goveramental affairs. This of course includes discussions of candidates, structures and forms of government, the manner in which government is operated or should be operated, and all such matters relating to political processes. . . Thus the press serves and was designed to serve as a powerful antidote to any abuses of power by governmental officials and as a constitutionally chosen means for keeping officials elected by the people responsible to all the people whom they were selected to serve."

Garrison v. Louisiana, 379 U.S. 64, 74-75 ( 1964 ) ("For speech concerning public affairs is more than self-expression; it is the essence of self-government."); New York Times Co. v. Sullivan, 376 U.S. 254, 270 ( 1964 ) ("Thus we consider this case against the background of a profound national commitment to the principle that debate on public issues should be uninhibited, robust, and wide-open, and that it may well include vehement, caustic, and sometimes unpleasantly sharp attacks on government and public officials."); Roth v. United States, 354 U.S. 476,484 (I957) ("The protection given speech and press was fashioned to assure unfettered interchange of ideas for the bringing about of political and social changes desired by the people."); Terminiello v. Chicago, 337 U.S. 1, 4-5 (1949):

"The vitality of civil and political institutions in our society depends on free discussion. As Chief Justice Hughes wrote in De Jonge v. Oregon, 299 U.S. 353,365 [(1937)], it is only through free debate and free exchange of ideas that government remains responsive to the will of the people and peaceful change is effected. The right to speak freely and to promote diversity of ideas and programs is therefore one of the chief distinctions that sets us apart from totalitarian regimes."

Musser v. Utah, 333 U.S. 95, IOI (I948) (dissenting opinion) ("It is axiomatic that a democratic state
} 
mental control over the public political forum may be practically as great as when an otherwise important segment of private opinion is suppressed outright, however, if the government itself commands sufficient means to propagandize so much, so continuously, and so loudly in support of one view that private voices feebly piping below the government's noisier din are scarcely heard. A government need not directly curtail the activities of private pamphleteers, for instance, if it can effectively displace them by subsidizing the "friendly" press or, better still, by establishing an inexhaustibly more powerful press committed exclusively to its own view.

At the same time, it is surely doubtful whether there is sufficient strength left to the doctrine of delegated powers to stop such governmental activities solely on the basis of a claim that the Constitution nowhere commits to Congress the power to spend in order to establish an exclusive governmental press. ${ }^{6}$ If standing to complain were to be found and a more solid constitutional basis for objection to be had, it would probably be in the theory of the first amendment:

Probably no one would suggest that Congress could, without violating this Amendment, pass a law taxing workers, or any persons for that matter (even lawyers), to create a fund to be used in helping certain political parties or groups favored

may not deny its citizens the right to criticize existing laws and to urge that they be changed."); De Jonge v. Oregon, 299 U.S. 353, 365 (1937):

"The greater the importance of safeguarding the community from incitements to the overthrow of our institutions by force and violence, the more imperative is the need to preserve inviolate the constitutional rights of free speech, free press and free assembly in order to maintain the opportunity for free political discussion, to the end that government may be responsive to the will of the people and that changes, if desired, may be obtained by peaceful means. Therein lies the security of the Republic, the very foundation of constitutional government."

Stromberg v. California, 283 U.S. 359,369 (I93I) ("The maintenance of the opportunity for free political discussion to the end that government may be responsive to the will of the people and that changes may be obtained by lawful means, an opportunity essential to the security of the Republic, is a fundamental principle of our constitutional system."); Whitney v. California, 274 U.S. 357, 377 (1927) (concurring opinion) ("Those who won our independence by revolution were not cowards. They did not fear political change."); United States v. Associated Press, 52 F. Supp. 362, 372 (S.D.N.Y. 1943) ("The First Amendment ... presupposes that right conclusions are more likely to be gathered out of a multitude of tongues, than through any kind of authoritative selection. To many this is, and always will be, folly; but we have staked upon it our all."); Paine, Rights of Man, in Basic Writings of Thomas Paine ${ }_{14 I}$ (1942) (" $[I] t$ is to a nation that the right of forming or reforming, generating or regenerating constitutions and governments belong [sic]; and consequently those subjects, as subjects of investigation, are always before a country as a matter of right, and cannot, without invading the general rights of that country, be made subjects for prosecution.").

See also Jefferson, Inauguration Address, in 3 The Writings of Thomas Jefrerson 317, 319 (Bergh ed. 1903); MrLI, On Liberty, in The Phisosophy of J. S. MrLL I85, 204 (Modern Lib. ed. I961); Edward G. Hudon, Freedom of Speech and Press in America (1963); Alexander Metrlejohin, Politicai Freedom (i960); Zechariah Chafee, Free Speech in the United States (2d ed. I94I); Brant, Seditious Libel: Myth and Reality, 39 N.Y.U.L. Rev. I (1964) (cf. LEONARD W. Levvy, THE LEGACY of SUPpression (I960)); Kalven, The New York Times Case: A Note on "The Central Meaning of the First Amendment," I964 Sup. CT. REv. 191; Emerson, Toward a General Theory of the First Amendment, 72 YALE L.J. 877 ( 1963 ); McKay, The Preference for Freedom, 34 N.Y.U.L. REv. II82 (1959).

Cf. Flemming v. Nestor, 363 U.S. 603 (1960); Ashwander v. TVA, 297 U.S. 228 (1936); New Brunswick v. United States, 276 U.S. 547 (1928); McCulloch v. Maryland, I7 U.S. (4 Wheat.) 316 (I819). See also Noel. T. Dowling \& Gerald Gunther, Constitutional Law Cases and Materials 368-70 (7th ed. 1965). 
by the Government to elect their candidates or promote their controversial causes. Compelling a man by law to pay his money to elect candidates or advocate laws or doctrines he is against differs only in degree, if at all, from compelling him by law to speak for a candidate, a party, or a cause he is against. The very reason for the First Amendment is to make the people of this country free to think, speak, write and worship as they wish, not as the Government commands. ${ }^{7}$

And again,

... I can think of few plainer, more direct abridgments of the freedoms of the First Amendment than to compel persons to support candidates, parties, ideologies or causes that they are against. ${ }^{8}$

The first amendment argument for silencing government internal propaganda is especially compelling as applied to media reaching captive and unwilling listeners. It draws strength from principles of privacy, as well as from the first amendment:

I am of the opinion ... that subjecting ... passengers to the broadcasting of news, public speeches, views, or propaganda of any kind and by any means would violate the First Amendment.

And, from the dissenting opinion in the same case,

When we force people to listen to another's ideas, we give the propagandist a powerful weapon. Today it is a business enterprise working out a radio program under the auspices of government. Tomorrow it may be a dominant political or religious group. ... [T] invaded, privacy is gone. ${ }^{10}$

Thus far, of course, this kind of problem has been largely hypothetical: ${ }^{11}$ the government has generally contented itself with the conduit of the private press for primary access to the public, and the Government Printing Office has not been regularly employed as a pipeline for any particular view. The political safeguards already built into our system surely provide a degree of continuing assurance for the future.

The difficulty of securing standing to silence government propaganda organs

${ }^{7}$ International Ass'n of Machinists v. Street, 367 U.S. 740, 788 (I961) (dissenting opinion).

${ }^{8}$ Lathrop v. Donohue, 367 U.S. 820, 873 (x96r) (dissenting opinion).

'Public Util. Comm'n v. Pollak, 343 U.S. 45I, 466 (I952) (separate opinion of Black, J.).

${ }^{10}$ Id. at 469 (dissenting opinion of Douglas, J.). See also Griswold v. Connecticut, 38I U.S. 479 (1965); Feiner v. New York, 340 U.S. 315 (1951); Breard v. Alexandria, 34 I U.S. 622 (I951); Kovacs v. Cooper, 336 U.S. 77 (1949); Saia v. New York, 334 U.S. 558 (1948); Martin v. Struthers, 3 I9 U.S. 14I (I943); Schwartz, The Mail Must Not Go Through-Propaganda and Pornography, II U.C.L.A.L. REv. 805, 851-58 (1964); Emerson, Toward a General Theory of the First Amendment, 72 YALE L.J. 877, 926-28 (1963); Ezer, Intrusion on Solitude, 21 LAw in Transition 63, 67-75 (x96r); Black, He Cannot Choose But Hear: The Plight of the Captive Auditor, 53 CoLUm. L. REv. 960 (I953).

11 The limited effort of the government to "inform" the people via official agencies established for that purpose during the Second World War, and the resistance of Congress to long-term and large-scalc projects of this kind, are reviewed in Zechariaf Chafee, Government and Mass Commumications 72734, 752-82 (1947). Our primary official information services today, Voice of America and USIA, provide information almost exclusively for foreign consumption. 
supported by the spending power is not an inconsiderable on $\mathrm{e}^{12}$ even with the aid of the first amendment ${ }^{13}$ and, moreover, the remedy of silence is generally not the way of the first amendment. ${ }^{14}$ It would appear far more likely that the first amendment might be employed with greater promise merely to establish a right of equal access to government-controlled publication media for the expression of dissenting views, rather than to establish a basis for silencing the government from presenting its own view. ${ }^{15}$ If the amendment could be so employed, however, the result obviously might tend more toward a general escalation in domestic propaganda from all sources with the government simply contending for its view in the greater cacophony of propaganda-a prospect not at all in accord with the direction suggested by Professors Whitton and Larson.

There is another respect in which serious constitutional questions might arise from positive-law efforts to suppress domestic propaganda originating within the government. A great deal of this propaganda originates with influential and newsworthy individuals within the government who simply rely upon the public spiritedness and competitive avarice of the private press to reach the public. ${ }^{16}$ It does not in-

\footnotetext{
13 See, e.g., Doremus v. Board of Educ., 342 U.S. 429 (I952); Perkins v. Lukens Steel Co., 3ro U.S. I13 (I940); Tennessee Elec. Power Co. v. TVA, 306 U.S. II8 (1939); Frothingham v. Mellon, 262 U.S. 447 (I923).

${ }^{13}$ But the involvement of a substantial first amendment issue probably does make a significant difference. See, e.g., Joint Anti-Fascist Refugee Comm. v. McGrath, 34I U.S. I23 (I95I); Oklahoma v. United States Civil Service Comm'n, 330 U.S. 127 (1947); Engel v. Vitale, 370 U.S. 421 (1962). For a most significant recent case, see Office of Communication of the United Church of Christ v. FCC, 359 F.2d 994 (D.C. Cir. I966). See also FCC v. Sanders, 309 U.S. 470 (I940); Scripps-Howard Radio, Inc. v. FCC, 3 I6 U.S. 4 (1942); Columbia Broadcasting Sys., Inc. v. United States, 3 I6 U.S. 407 (I942); Anti-Defamation League v. Station KTYM, No. 66-545, FCC, June I7, I966, 34 U.S.L. WEEK 2718 (U.S. June 28, I966); Louis L. JafFe, Judicial Control of Administrative Action 459, 545 (I965); Davis, "Judicial Control of Administrative Action": A Review, 66 Colvm. L. Rev. 635, 659-69 (I966); Berger, Administrative Arbitrariness and Judicial Review, 65 ColvM. L. Rev. 55 (I965); KENNETH C. Davis, Administrative Law Treatise $\$ 28.16$ (Supp. 1965); articles by Berger and Davis, II4 U. PA. L REv. 783, 814, 816, 823 (1966); Sedler, Standing to Assert Constitutional Jus Tertii in the Supreme Court, 7Y YALE L.J. 599 (I962); Lewis, Constitutional Rights and the Misuse of "Standing," I4 Stan. L. REv. 433 (I962); Sutherland, Establishment According to Engel, 76 HARv. L. REv. 25 (I962); Gunther, The Subtle Vices of the "Passive Virtues"-A Comment on Principle and Expediency in Iudicial Review, 64 Colun. L. Rev. I (1964); Alexander M. Bickel, The Least Dangerous Branch-The Supreme CoURT AT THE BAR of Politics ( 1962 ). Without doubt, the single most infuential factor is whether Congress has expressly attempted to grant standing.

14 See, e.g., Whitney v. California, 274 U.S. 357, 377 (r927) (concurring opinion): "If there be time to expose through discussion the falsehood and fallacies, to avert the evil by the processes of education, the remedy to be applied is more speech, not enforced silence."

${ }^{20}$ A useful analogy may be found in the FCC's development of the "fairness" doctrine and the responsibilities of licensees under the Communications Act. See 73 Stat. 557 (I959), 47 U.S.C. $\$ 3$ I5 (a) (I964); Editorializing by Broadcast Licensees, I3 F.C.C. 1246, 1249 (1949); Office of Communication of United Church of Christ v. FCC, 359 F.2d 994 (D.C. Cir. 1966). See also Emerson, Toward a General Theory of the First Amendment, 72 YALE L.J. 877, 954 (1963) ("Where the government voice is not the exclusive one in a field, but must compete with expression by private individuals or groups, there is less need of limitation.").

${ }^{10}$ See William H. Irwin, Propaganda and the News 247 (1936); Harold D. Lasswell, National SECURITY AND INDIVIDUAL FreEdom 95 (1950). Studies of the government's role in shaping public opinion have emphasized the importance of relay by the private sector. Lester Markel, Public OpINIoN and Foreign Policy passim (I949); James L. McCamy, Government Publicity I06-08 (I939).
} 
volve governmentally owned presses or broadcast facilities dedicated to the espousal of an official line, but it simply counts upon the regular press for its ready dissemination. Short of efforts being made to curtail the freedom of the private press, the effective suppression of such propaganda would require the application of sanctions against the very government officials with whom the incendiary utterances originate.

Within our own municipal law system, however, there are grave doubts respecting the constitutionality of laws designed to suppress such utterances or to punish those Presidents or congressmen who choose to exploit the advantages of their offices for propaganda purposes. Even if an Attorney General could be found so brash as to be willing to prosecute, for instance, it is not at all clear that presidential prerogatives and immunities could be stripped away to prevent the President from "going directly to the people" to promote an aggressive war, to encourage the subversion of foreign regimes, or to defame foreign governments. Neither does it seem likely that Congress would seek to impeach him for thus committing some high crime or misdemeanor, even assuming that it had previously adopted some statute suitable for the purpose and that the remedy thus selected were somehow placed beyond judicial review. Isn't it equally doubtful whether warmongering propaganda on the floor of Congress or on the hustings could be made the subject of punishment in view of the congressman's own immunity and his own first amendment rights? ${ }^{17}$ And may it not be the case that these traditional varieties of government propaganda have in fact played the more substantial role to inflame the public passion with a considerable tendency to breach the international peace?

To note the public's lack of constitutional standing to compel governmental officials to propagandize domestically may possibly be useful. But to make this observation is not to observe much about the manner in which many officials frequently give way to dangerous diatribe, yielding to pressure, duty, opportunism, or plain impulse. Nor is it to observe anything whatever about the constitutionality or enforceability of positive-law attempts-within our own courts and under our own laws (whether or not pursuant to a treaty)-to punish those officials for breaking silence.

\section{II}

\section{Government Control of Propaganda From Abroad}

The issues here tend to cluster about two fairly distinct situations involving the capacity of government to suppress propaganda from foreign sources. The first

\footnotetext{
${ }^{17}$ See, e.g., United States v. Johnson, 383 U.S. 169,179 (1966) ("The legislative privilege [Art. I, Sec. 6], protecting against possible prosecution by an unfriendly executive and conviction by a hostilc judiciary is one manifestation of the 'practical security' for ensuring the independence of the legislature."); New York Times Co. v. Sullivan, 376 U.S. 254 (1964); Howard v. Lyons, 360 U.S. 593 (1959); Barr v. Matteo, 360 U.S. 564 (1959); Tenny v. Brandhove, 34I U.S. 367 (I95I); Spalding v. Vilas, I6I U.S. 483 (r896); Kilbourn v. Thompson, I03 U.S. I68 (I88r); Gregoire v. Biddle, I77 F.2d 579 (2d Cir. 1949), cert. denied, 339 U.S. 949 (1950); Comment, The Bribed Congressman's Immunity From Prosecution, 75 YALE L.J. 335 (I965); WhItTON \& LARSON I64-66; 2 G. H. HACKWORTH, Digest or INTERNATIONAL LAW I44-45 (I94I).
} 
situation may arise from decisions by the government simply to refuse to serve as a relay station or information center for propaganda originating abroad but not otherwise accessible to private citizens through private channels. Such propaganda may be generally inaccessible because it involves information originally and exclusively gathered by government agencies and not otherwise made available by foreign sources to private correspondents. The second situation involves foreign propaganda which would be widely available to the public in the absence of affirmative action by our own government to shut off access (e.g., by restrictions on travel abroad, by curtailing the mail, and by regulating the penetration of foreign broadcasting). Quite obviously, there is a broader range of constitutional problems presented by the more varied devices of control in this second situation.

Professors Whitton and Larson generally foresee little constitutional difficulty arising from either situation: certainly not from the first situation because, again, "the problem of freedom of speech in the constitutional sense simply does not arise when the government itself is doing the speaking," and simply decides not to speak. But we are here concerned with the effective capacity of the government to censor itself as an exclusive source of information coming from abroad against the general objection that a refusal by government to share such information with the people necessarily prejudices the public's right to know and their right ultimately to determine domestic and foreign policy with that knowledge in mind. Because "propaganda" has been defined so broadly, ${ }^{18}$ Professor Newhouse is correct in suggesting that such propaganda may still constitute "information which, by hypothesis, is 'necessary' for an 'informed' citizenry on matters of public policy."19 Whether what is being said abroad is true or false, laudatory or defamatory, it may still be important to know that it is being said if the people themselves are to exercise an untrammeled right to determine their own collective response to it.

If Professors Whitton and Larson are correct in their view that the government

${ }^{18}$ Whitton \& Larson 8-1 $, 62-65,83$, ro4. Synthesized from $i d$. at 9, the type of "propaganda" which the authors attempt to show is forbidden by international law may be defined this way: "the use of facts, fiction, argument and suggestion, sometimes supported by an effort to suppress inconsistent material, with the calculated purpose of instilling in the recipient certain beliefs, prejudices, or convictions which will serve the interest of the author, usually by producing or tending to produce a certain line of action. ... There is a line which our analysis will try to draw .... The essential feature of this 'over the line' propaganda is that it tends to produce a breach of peace."

Professor Newhouse properly notes the first amendment objections of vagueness and overbreadth which would necessarily be raised by the enactment of "breach of [international] peace" antipropaganda statutes. Newhouse, text accompanying notes $65-69$. I agree, even while recognizing the possibility that a court sympathetic to such federal legislation might attempt to rescue it by a saving and narrow interpretation. The trend, however, is entirely the other way, and it merits mention that broad breachof-peace statutes are still tested as well under a rigorous clear-and-present-danger test. In addition to the cases cited by Professor Newhouse, especially Elfbrandt v. Russell, 384 U.S. II (Ig66), see Ashton v. Kentucky, 384 U.S. I95 ( 1966 ); Dombrowski v. Pfister, 380 U.S. 479 (I963); Cox v. Louisiana, 379 U.S. 536, 552 ( 1965$)$; Fields v. South Carolina, 375 U.S. 44 (1963); Edwards v. South Carolina, 372 U.S. 229 (I963); Garner v. Louisiana, 368 U.S. I57 (I96I); Terminiello v. Chicago, 337 U.S. I (I949); Cantwell v. Connecticut, 310 U.S. 296 (1940). See note 56 , infra.

${ }^{19}$ Newhouse 507 n.8. 
need not (must not?) share such information or report such propaganda solely on the grounds that it is illegal propaganda (and not, for instance, on the more narrow basis that its untimely release would also imminently threaten national security), it may only be in the strict sense that private citizens may lack standing to compel such a sharing if Congress elects to deny such standing. ${ }^{20}$

But we have already noted that the government itself is by no means univocal, and substantial constitutional issues not confined to the first amendment may still arise depending upon the extent to which those officials on whom silence is imposed may still choose to speak. For instance, we must surely doubt the efficacy of a statutory attempt to prohibit the President from releasing to the public incendiary propaganda acquired by him even in his official capacity. One may also doubt whether even a subordinate administrator could effectively be forbidden by the President, on the other hand, from relaying information acquired through his office, or from airing a vituperative statement based on such information, in the course of testifying before a congressional committee-especially if he were first willing to pay the price of resigning from his post. Could a member of Congress be prevented from broadcasting such "classified" propaganda acquired solely in his official capacity, either by revealing it on the floor of Congress or by addressing it to his constituents? In short, may not positive-law attempts to restrict the government from relaying foreign propaganda again be only as effective as the scarcely controllable discretion of those within the government? ${ }^{21}$

Where the government itself has no monopoly over foreign sources of propaganda, moreover, and where the propaganda may freely penetrate the country to be received by anyone willing to receive it unless the government acts affirmatively either to shut it out or to threaten those who would listen, substantial constitutional issues definitely become involved. To be sure, governmental regulation of transmitting frequencies solely to protect internal communication between domestic broadcasters and those who would hear them may be necessary, reasonable, and constitutionally unobjectionable. The foreign broadcaster probably has no first amendment standing, and the interests of those who might wish to hear him may nonetheless be subordinated in a neutral fashion (i.e., not based on the politics of the broadcast) to the extent that natural limitations of the receiving medium require that a choice be made by government if anyone at all is to hear and to broadcast within the country without interference. ${ }^{22}$

\footnotetext{
${ }^{20}$ See notes $I_{2}$ and $\mathrm{I}_{3}$ supra.

${ }^{21}$ See note 17 supra.

${ }^{22}$ The rationale is drawn by analogy from the the FCC's licensing authority to elect between mutually exclusive applicants, from the parliamentary order concession explicit in Professor Meiklejohn's writings [e.g., Political Freedom 24-26 (I960)], and from the assumption that in situations where either the foreign or the domestic broadcaster must yield if either is to be heard, a preference for the citizen would be upheld. It may also be argued that even foreign broadeasts over unused frequencies within the United States might be curtailed by treaty or jamming, to protect the economic sufficiency of local broadcasters otherwise unable to maintain themselves.
} 
Sharing Professor Newhouse's doubts, however, I cannot agree with the general statement by Professors Whitton and Larson that "any country can stop printed materials at its borders and thereby obliterate almost completely any effect these printed materials might have on its own people."23 As applied to the United States, I take this statement to mean that positive executive or legislative action effectively sealing off the country from propaganda originating outside the country would be constitutionally unobjectionable, whether or not there may be persons within the United States interested in receiving such material. But Professor Newhouse is quite right to note the flavor, as well as the holdings, of Lamont ${ }^{24}$ and Aptheker ${ }^{25}$ (both of which were decided since the Whitton and Larson book was published). Nor is the decision in Zemel ${ }^{28}$ one which looks altogether in a different direction. Indeed, the fact that direct access to foreign sources may be restricted by limiting the right to travel under some circumstances only makes it more important that at least vicarious access to foreign sources, not involving the complicating by-products associated with personal travel to troubled areas, must not be generally foreclosed. If it is true that the government has no enforceable duty to relay information which it receives, moreover, the right of willing addressees at least to receive and to read what others are willing to send directly to them is all the more compelling.

Need we say again that a central function of the first amendment is to preclude governmental determinations of the political forum? The amendment safeguards "the maintenance of the opportunity for free political discussion to the end that government may be responsive to the will of the people"27 and not to the end that the people may be responsive to the will of the government, not on condition that that will shall be formed only on the basis of information first sifted by government for falsehood and dangerous tendencies, and not even necessarily to the end that the will of the people shall uniformly serve peaceful purposes. "The constitutional protection does not turn upon the truth, popularity, or social utility of the ideas and beliefs which are offered." ${ }^{\text {"28 }}$ To the contrary, the short-term operative truth, popularity, and utility of an idea for purposes of consequential governmental action are pragmatically assimilated in the political outcome of the debate which occurs without governmental predisposition, ${ }^{29}$ subject only to judicial review. A person allowed to listen only to local sources of news is obviously without freedom to catch ideas

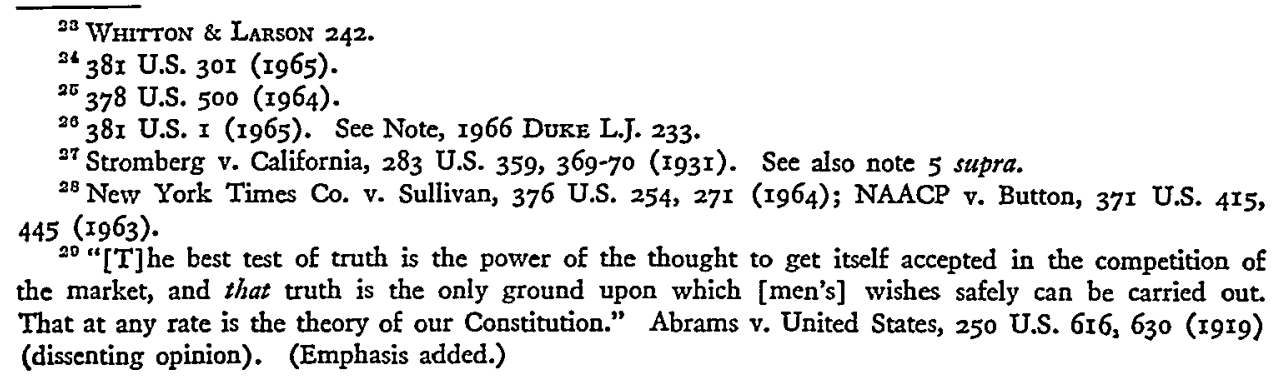


and to determine the opinion he may then choose to cast in affecting that political outcome: certainly this is so in matters respecting foreign policy.

The right to hear has always been indispensable to the constitutional utility of the first amendment, and the decision in Lamont was entirely overdue. Attempts to close out all foreign propaganda at the borders should therefore be nearly as vulnerable to first amendment objections as attempts to make it a criminal offense for one to read anything that somehow gets through. As in Lamont itself, the only serious issue here is that of securing standing to protest a general ban to the extent that the material sent from abroad is not addressed to any particular receiver. The problem of standing, however, should not be insurmountable..$^{30}$

\section{III}

\section{Government Control of Private American Propaganda}

Most of Professor Newhouse's paper is devoted to a treatment of this third area: first amendment issues which might be raised were the government to discharge its alleged international law obligation to suppress private propaganda originating with American citizens or organizations. For reasons shortly to be made obvious, it may be useful to divide this propaganda into that designed for foreign consumption and that designed for consumption within the United States.

Although the first amendment speaks of the freedom of speech without qualification, I believe that an easy case can be made that the government is not constrained to permit private propaganda to be beamed abroad in conflict with a given foreign policy which is itself fully subject to popular review. If that policy is, at the time in question, not to unsettle international relations through propaganda designed to overthrow foreign governments by arousing their people against them, and not to urge one country to undertake an aggressive war against another, for instance, I have little doubt that the policy can also be enforced against private groups whether or not they would prefer a different policy. Similarly, feasible sanctions are doubtless available against private American organizations which might seek to operate propa. ganda centers outside the country but which must preserve some source of support within the country or which involve citizens who might someday like to come home without fear of prosecution. The critical distinction, of course, is that such propaganda is not, by definition, interior to the democratic process. It is not addressed to our public forum, to sear our consciences and to agitate for a change either in the policy in question or in any other policy or law within our own ideological marketplace. To the contrary, given a duly adopted policy of our own, such propaganda proceeds to agitate elsewhere in direct conflict with that policy. Nothing in the functions of the first amendment requires that the executive and legislative powers over foreign affairs yield so far to private departments of state.

We reach a different question, however, in considering private propaganda orig-

\footnotetext{
${ }^{80}$ See Lamont y. Postmaster General, $38 x$ U.S. 30r (1965); cases cited supra note I3.
} 
inating within the United States and designed primarily for domestic consumption. Presumably the type of propaganda to be controlled here is primarily warmongering propaganda, since the other two types are more characteristically for foreign, rather than domestic, consumption except to the extent that defamation of foreign governments may be subsumed in warmongering. ${ }^{31}$ Here, at least, it is conceded by all that first amendment issues do intrude. At the same time, even this aspect of the subject has been introduced apologetically, since Professor Newhouse concedes that the problem of private warmongering propaganda for home consumption "is of relatively little real consequence." ${ }^{32}$ In this regard, he agrees with Professors Whitton and Larson "that the really dangerous items are in modern times almost entirely governmental in origin."33 The need to control private propaganda for domestic consumption is apparently not a question of national survival or of avoiding significant threats to international peace. It is, rather, merely a need to demonstrate good faith (i.e., the "propaganda" value of suppressing ineffective propaganda at home) ${ }^{34}$ and possibly to "anticipate and block the development of any such kind of activity in case anyone is tempted to try this sort of thing in the future."35

What appears to have gone unnoticed, however, is that the claimed insignificance of private propaganda tends to destroy the case for its governmental suppression. Paradoxically, the success of the persuasion that the field of first amendment intrusion is trivial simultaneously tends to show that the kinds of control believed to be salutary would nonetheless be unconstitutional. If the breach of international peace is the substantive evil to be avoided by propaganda control, and if that evil cannot be said to be threatened by occasional outbursts of private warmongering propaganda, which is stipulated to be too poor and puny, where is the overriding necessity which alone can justify the subordination of freedom of speech ?36 Would the lesser purpose merely of proving our good faith or of providing a "wholesome" example be a sufficient substitute? It appears very doubtful.

Personally, however, I believe that a discussion of governmental control of domestic warmongering propaganda needs no apology on the ground that the subject is trivial. To the contrary, I am inclined to think that private sources of propaganda historically have been a powerful contributing force to the development of war tensions, at least within the United States where private communication media have predominated. ${ }^{37}$ Certainly this has been so on those frequent occasions when

\footnotetext{
${ }^{31}$ See Manuel R. García-Mora, International Responsibility for Hostile Acts of Private Persons Against Foreign States 89 n.42 (1962).

${ }^{32}$ Newhouse 507 .

${ }^{33}$ Whatron \& LARSON 242.

34 See Newhouse 507 .

36 WhITTON \& LARSON 240.

${ }^{30}$ See Abrams v. United States, 250 U.S. 6r6 (rgrg) (dissenting opinion). See also note 56 infra.

${ }^{37}$ The Whig newspapers were a significant voice in America's early war with the British. PrILIP Davidson, Propaganda and the American Revolution 225-45 (I94I). The years prior to the Spanish-American War witnessed one of the most dramatic examples of press creation of war tensions. Marcus M. Wilkerson, Public Opinion and the Spanish-American War: A Study in War Propa-
} 
the propaganda of the private mass media has served to relay, amplify, intensify, encourage, and reciprocate the government's own propaganda. ${ }^{38}$

The very fact that the private press has frequently worked in harness with government, to inundate the public with "facts, fiction, argument and suggestion ... building up incidents or ideas that will bring on war," 39 however, should make us pause in assessing the probable effects of legislation empowering government to suppress private propaganda. Before approving any more national legislation ostensibly designed to protect our national survival through the silencing of speech $^{40}$

GANDA (1932); Auxier, Mid-Western Newspapers and the Spanish-American War, 26 Miss. Hist. REv. 523-34 (1940). In the period before America's entry into the Second World War, the private press produced a large volume of war propaganda [see HARold Lavine \& J. A. Wechisler, War Propaganda AND THE UNITED STATES (1940)], much of it reaching the American public due to the maneuvering of the British propagandists. See Horace C. Peterson, Propaganda for War (I939). On various occasions, statements published in American newspapers have sufficiently provoked forcign governments that they have made formal protests to the Department of State. See Dickinson, The Defamation of Foreign Governments, 22 AM. J. INT'I L. 840 (I928); GARcíA-MORA, op. cit. supro note 31 , at 82 \& n.I4, 87-88; 2 G. H. HACKWORTH, DigesT OF INTERNATIONAL LAW 140-4I, r45-46, 338 (r94I); 7 id. at 394 (1943). Development of war-tensions by private publications is not peculiar to the United States. See Preuss, International Responsibility for Hostile Propaganda Against Foreign States, 28 AM. J. INT'z I. 649 (1934).

${ }^{38}$ The private press tends to function in harness with the government not only by printing routine "news" which is released calculatingly by the publicity men of government agencies (see generally McCAMY, op. cit. supra note 16 ) but also by publicizing the government's views and statements during times of crisis. The faithfulness of the private press in relaying, amplifying, and reciprocating the government's own propaganda was evidenced before and during the American Revolution, Davidson, op. cit. supra note 37, at 225-45, the First World War, George Crees, How We Advertised America (1920), and the Second World War, Frederick C. Irion, Public Opinion and Propaganda 410.52 (1950). Within the family of government officials, the President of the United States has occupied the most advantageous position to utilize the private press in carrying the government's views. JAMEs E. Pollard, The Presidents and the Press (1947); Janses E. Pollard, The Presidents and the Press: From Truman to JoHnson (1965). Even when the editorials of particular newspapers have disagrced with the positions taken by the government, namely the President, the public may be more effectively influenced by the same papers' news columns accurately printing the government's statements. LEONARD W. Doob, Public Opinion and Propaganda 429-40 (I948).

${ }^{39}$ WhitTon \& Larson 9-10.

${ }^{10}$ The Sedition Act of I794, ch. $50, \S 5$, I Stat. 384 [now I8 U.S.C. $\S 960$ (I964)], was a statute forbidding the setting on foot or preparing to set on foot any military or naval expedition or enterprise against the territory of a foreign state. See note 74 infra and accompanying text. Although the thrust of the statute is aimed at overt acts and conduct, and although courts have uniformly required more than mere speech relating to the proscribed act, Garcís-Mors, op. cit. supra note 3I, at 53-58; 7 G. H. HACKwORTH, Digest OF INTERNATIONAI LAW 396-404 (1943), some commentators have advanced the contention that the statute could be used to punish certain forms of speech, such as "the use of words to plan, organize, equip, finance, transport or in other tangible ways forward the forbidden venturc." WhITTON \& LARSON 239. See notes 74-75 infra and accompanying text.

The first federal statutes clearly to discourage freedom of political expression werc the Alien Act, ch. 58, § I, I Stat. 570 (r798), and the Enemy Alien Act, ch. 66, § r, I Stat. 577 (1798). "The Alien Act and the Enemy Alien Act were never formally invoked but their very existence forced a number of aliens to leave the country or go into hiding. By their terms these acts expired in two years." I Thossas I. Emerson \& David Haber, Polmical and Civil Rights in the United States 277 (2d ed. 1958). Working in harmony with the Alien Act and the Enemy Alien Act was the Naturalization Act, ch. 54, $\$ \S \mathrm{I}, 4$, I Stat. 566 ( $\mathrm{I} 798)$, which lengthened the residence requirement period for naturalization from five to fourteen years.

In conjunction with the Alien Act, the Sedition Act of I798, ch. 74, I Stat. 596, represented the most serious challenge to the freedom of expression. Section 2 of the Sedition Act contained prohibitions against speech in either the printed or spoken form. Although $\S 3$ of the act stated that the defendant in the 
said to tend to breach the international peace, we need to pause over the fact that it will almost inevitably be the government itself which will decide when and against whom to apply that legislation. Such laws as we may develop will lend themselves to executive misapplication against a minority press singled out because it is publishing strident criticism of a given national policy and not because it poses the more significant threat to international peace. ${ }^{41}$

particular case could offer in his defense to the libel charge evidence of the truth of his speech, "juries, with the power of ruling on the guilt or innocence of alleged libels, proved to be as susceptible to prevailing prejudices as judges when they decided the fate of defendants who had expressed unpopular sentiments. Only one verdict of 'not guilty' was returned in the numerous prosecutions under the Sedition Act of I798." LEVY, op. cit. supra note 5, at I3I. Although the number of those convicted (all being members of the Republican Party) was not large, "it is generally agreed that the Alien and Sedition laws profoundly shocked the country and were a major factor in the defeat of the Federalists in the election of 1800 . The Sedition Act expired on March 3, 180r. Jefferson pardoned all those who had been convicted under it and eventually Congress repaid most of the fines." I EMERSON \& HABER, op. cit. stupra, at 278. For a comprehensive presentation of the Alien and Sedition Acts, see JAMEs F. SMIth, FREEDOM'S FETTERS (1956).

Between the expiration of the Sedition Act of $x 798$ in $I 80 \mathrm{or}$ and the passage of the Federal Espionage Act in 1917 , ch. 30,40 Stat. 217 [now I8 U.S.C. \$\$ 792-94, 2388 (1964)], although no national antisedition legislation as such was enacted, various laws were employed to discourage free political discussion and expression. I EMERson \& HABER, op. cit. supra, at 279-84. Some of the normal federal laws which can be used and have been used to curb free speech are the conspiracy laws regarding the overthrow of the United States Government, e.g., I8 U.S.C. $\$ 2385$ (I964); the constitutional provisions against treason, U.S. CoNST. art. III, $\S 3$; the statute forbidding rebellion and insurrection, I 8 U.S.C. $\$ 2383$ ( 1964 ); the law against seditious conspiracy, I8 U.S.C. $\$ 2384$ ( 1964 ); and other laws prohibiting offenses against the United States, e.g., I8 U.S.C. \$\$ I-8 (1964). See Zechariar ChafeE, FreE SPeEch IN THE UNITED STATES I 4 I-68 (2d ed. I94I).

In 1917, Congress reacted to the pressures generated by the war and enacted the Federal Espionage Act. When it was felt that the Federal Espionage Act was not broad enough in its coverage of disloyal and seditious expression [see 4 A.B.A. J. 306 (I918)], further sweeping prohibitions against freedom of expression were enacted in an amendment to the Federal Espionage Act, ch. 75, 40 Stat. 553 (I918), which was later repealed, ch. I36, 4 I Stat. I359 (I92I). See Chafres, op. cit. supra, at 37-4I, 50-52, IO0-0I; 7 John Bassett Moore, Digest of INTERNational Law 908-34 (x906).

The period following the Second World War witnessed even broader legal restrictions on freedom of speech, most notably the Smith Act of 1940 , I8 U.S.C. $\$ \$ 2385,2387$ (1964); the Internal Security Act of 1950, 64 Stat. 987-1002, 1019-30, 50 U.S.C. $\$ \$ 78 \mathrm{I}-94,8 \mathrm{II}-26$ (1964); and the Communist Control Act of 1954,68 Stat. $775-76$, 50 U.S.C. $\$ \$ 84 \mathrm{I}-44$ ( 1964 ). See also the various federal statutes requiring registration or disclosure of certain information such as the Foreign Agents Registration Act, 52 Stat. $63 \mathrm{r}$, as amended, 75 Stat. 784 (196r), 22 U.S.C. $\$ \$ 6 \mathrm{rI}-2 \mathrm{I}$ (1964); the Alien Registration Act, 66 Stat. 223 (1952), 8 U.S.C. $§ \S 1301-1306$ (1964); the Federal Corrupt Practices Act, 43 Stat. I070 (1925), as amended, 2 U.S.C. $\$ \$ 24 \mathrm{r}-56$ (I964); and the Federal Regulation of Lobbying Act, 60 Stat. 839 (I946), 2 U.S.C. $\$ \$ 26 \mathrm{r}-70$ (1964). See Note, Registration of Groups Tending to Influence Public Opinion, 48 CoLUM. L. Rev. 589 ( 1948 ).

The denial of significant non-speech interests of alleged subversives has doubtless affected unfettered political discussion. I EMERSON \& HABER, op. cit. supra, at 547-52. Besides the constraining laws dealing with the areas of access to the election process, of engaging in a legal career, and of the issuance of passports and freedom of movement, $i d$. at 475-52I, there has been restrictive legisiation pertaining to the following: union officials, the Labor Management Relations Act, ch. I20, $\$ 9(\mathrm{~h}), 6 \mathrm{I}$ Stat. I 43 (1947), repealed, ch. 534, $\$ 20 x$ (d), 73 Stat. 525 (1959); aliens, the Immigration and Nationality Act of 1952,66 Stat. $166-273,8$ U.S.C. $\$ \S 110 I-1503$ (1964); expatriation, the Expatriation Act of 1954,68 Stat. $x{ }_{4} 6,8$ U.S.C. $\$$ I48I(a)(9) ( 1964$)$; and loyalty-security qualifications for employment, the Hatch Act, ch. 410, $\$ 9$ (a), 53 Stat. II 48 (I939), repealed, ch. $690, \S_{4}$ (2), 69 Stat. 625 (1955).

${ }^{11}$ The Sedition Act of I794, ch. 50, \$5, I Stat. 384 [now I8 U.S.C. $\$ 960$ (I964)] (see note 40 stupra), was employed to the disadvantage of the Republican Party. "Republican newspapers were scanned for seditious material and prosecutions were brought against the four leading Republican papers as well as against some of those less influential. Cases were also instituted against at least three of the more outspoken Republican office holders." I EMERSON \& HABER, op. cit. supra note 40, at 277. After 
Our present predicament provides a number of plausible illustrations of the danger that such legislation could be subverted in the ends of its application. Under the definitions tendered by Professors Whitton and Larson, ${ }^{42}$ much of the information regarding Vietnam that is distributed by government and amplified by the press today is doubtless warmongering propaganda. Whether it is also in the national interest according to the better view, or whether it contributes to slight breaches of peace today in order to avoid more catastrophic ones tomorrow, may be fairly debatable but need not be debated here. In any case, the government has found this propaganda to be useful, and for our purposes it is sufficient to suggest the unlikelihood that any statutes we might have adopted to control private warmongering propaganda would be applied by the government against that segment of the press which fully, if sometimes irresponsibly, amplifies the government's own statements and propagandizes in favor of the government's own policies. If pressed for an explanation, the government could be expected to take the position that such statutes were not being violated in view of its claim that our commitment in Vietnam is sanctioned by international law..$^{43}$ Private propaganda which merely supports that commitment, it might say, consequently does not involve an American threat to the kind of breach of peace (i.e., the threat of an aggressive war) condemned by international law.

the Federalists were defeated in the election of 1800 and Jefferson had pardoned all persons convicted under the Sedition Act of 1794 , Federalist newspapers were prosecuted for seditious libel. LeonarD W. LeVY, JefFerson and Givil Liberties 59-66 (1963). In discussing the two thousand prosecutions under the Federal Espionage Act, ch. 30, 40 Stat. 217 (1917) [now 18 U.S.C. $\$ \$ 792-94,2388$ (1964)] [see Schenck v. United States, 249 U.S. 47 (1919), and note 40 suppra], and the amendment thereto, ch. 75, 40 Stat. 553 (19I8), repealed, ch. I36, 4 I Stat. I359 (I92I) [see Abrams v. United States, 250 U.S. 616 (I9r9)], one commentator has stated that "the courts treated opinions as statements of fact and then condemned them as false because they differed from the President's speech or the resolution of Congress declaring war. Almost all the convictions were for expressions of opinion about the merits and conduct of the war." Zechariah Chafee, Free Speech in the United States 5 I (2d ed. I941). During this period the states were not without laws designed to suppress minority press. In Gitlow v. United States, 268 U.S. 652 (1925), the Supreme Court upheld New York's criminal anarchy statute by confirming the convictions for the printing and circulating of a paper entitled "Manifesto," which encouraged the aims of the "Communist Revolution." Using both the Federal Espionage Act and the Smith Act of 1940,18 U.S.C. $\$ \$ 2385,2387$ (1964), the Justice Department initiated the widely publicized sedition trials of 1944. See Maximilian St.-George \& Lawrence Dennis, a Triat on TRIAL (r946).

Professor Chafee has offered the following four summary observations regarding the sedition laws of this country up to the Smith Act:

"(I) The persons punished were for the most part unimportant and comparatively harmless. ...

"(2) The suppressions of one period are condemned a generation afterwards-or much sooner -as unnecessary, unwise, and cruel....

"(3) The main principles of the speeches and pamphlets which a government made vigorous attempts to suppress are often put into force within a few decades. ...

"(4) History shows that sedition is often the symptom and not the cause of serious unrest. ..."

Chafee, op. cit. stupra, at 513-16.

22 See note 18 supra.

${ }^{4} 54$ Dep't State Buzl. 474 (I966). But see Memorandum of Law by Lawyers Committee on American Policy Towards Vietnam, reprinted in III Conc. Rec. 2401 I-I 8 (daily ed. Sept. 23, 1965). 
On the other hand, such statutes might still be applied to those propagandizing for our defeat in Vietnam or for our withdrawal from the area. The unhappy professor who spoke for a Vietcong victory, ${ }^{44}$ and the draft-card burners dramatizing their dissatisfaction with our efforts, ${ }^{45}$ could be described as engaging in warmongering propaganda. Their expressive activities might be said to be calculated to embolden the North Vietnamese to press an aggressive (and therefore forbidden) war. Similarly, while Senator Morse may be protected by legislative immunity from prosecution under a statute forbidding defamatory propaganda for his announced opinion about the character of the South Vietnamese government, ${ }^{46}$ news columnists might be successfully prosecuted for identical utterances. They could be charged with the felony of "defamatory propaganda," utterances tending to bring a foreign government into disrepute with its own or other people and tending therefore to increase tension between that friendly government and our own. Identically inaccurate or accurate statements by the private press about the character of the North Vietnamese regime, on the other hand, would surely be less likely to precipitate action by the executive within whose discretion the power to prosecute rests.

The point is obvious and serves merely to illustrate the uneasy feeling Professor Newhouse expressed in the conclusion to his paper. The formulation of national legislation may be neutral in its intendment, good in purpose, and nondiscriminatory on its face. But the discretion of the executive to pick and choose the occasions for its employment, and the occasional pressure of public passion to have him exercise that discretion in invidious ways, cannot safely be disregarded. Our own history should make us aware of the possibility that statutes of this kind may be deflected from serving norms of international law and subordinated to the service of distinctly national-sometimes nationalistic-policies. ${ }^{47}$

It may not be enough of an answer, in these circumstances, to point out that these risks are always present in the administration of criminal law and that they are amply considered in the general provision we have made for an independent federal judiciary with its ameliorative powers of statutory interpretation and constitutional review. Care must still be taken to avoid the impulsive establishment of crude laws while banking on the Court to sort the good from the bad-especially in times of crises, ${ }^{48}$ especially where Congress finds legislative facts said to affect national

\footnotetext{
"N.Y. Times, June 23, x965, p. 9, col. 3 ; id., Sept. 13, 1965, p. 9, col. 1; id., Oct. I9, 1965, p. 30, col. 5 ; id., Oct. 25 , I965, p. I, col. 6. See 52 A.A.U.P. Burz. 2 II (I966).

${ }^{15}$ See 50 U.S.C.A. App. $\$ 462$ (I964); United States v. Smith, 249 F. Supp. 5I5 (S.D. Iowa Ig66); United States v. Miller, 249 F. Supp. 59 (S.D.N.Y. I965), 34 ForD. L. REv. 7I7 (I966); Forkosch, Draft Card Burning-Effectuation and Constitutionality of the 1965 Amendment, 32 BRookLYN L. REv. 303 (I966); Rachlin, Draft Cards and Burning the Constitution, 32 Brookrys L. Rev. 334 (I966); Finman \& Macaulay, Freedom to Dissent: The Vietnam Protests and the Words of Public Officials, I966 WIs. I. REv. 632.

${ }^{10}$ III CoNg. Rec. I6527-3I (daily ed. July I6, I965) (remarks of Senator Morse).

" "See note 4 I supra; Leonard W. LeVy, Legacy of Suppression (Ig6o).

${ }^{8}$ Zechariah Chafee, Free Speech in the United States 563 (I94I): "The Supreme Court,
} 
survival ${ }^{4 \theta}$ and foreign affairs, ${ }^{50}$ and especially where the occasions of enforcement remain-as they must-essentially a matter of executive discretion. As to the last of these considerations, it is by no means clear that the doctrine of Yick Wo would be fully adequate to minimize the risk of unequal application of the law. ${ }^{\mathbf{W 1}}$

The source of discomfort goes beyond the observation that only once in 175 years enclosing a multitude of antisedition laws employed in hundreds of federal prosecutions, has a federal statute actually been held unconstitutional under the first amendment. ${ }^{52}$ It also goes beyond the practical point that Justices such as Black and Douglas may be succeeded by Justices with vision as different as that possessed by those succeeding Justices Murphy and Rutledge, ${ }^{53}$ or that even the toughest judicial fibre will sometimes yield. ${ }^{54}$ The discomfort is traceable more substantially to the quicksilver quality of first amendment doctrines ${ }^{55}$ and to the ease with which a court might find that legislation dealing with the slow, insidious evils of propaganda cannot be reviewed for constitutionality by any standard as "ill adapted" as the stringent clear-and-present-danger test. ${ }^{56}$ That test, as Professor Kalven so usefully pointed

though much more anxious to support liberty of speech than it was twenty years ago, can do nothing to keep discussion open during an emergency." Charles H. Pritchetr, Civil Liberties and tuis Vinson Court (1954); Alfange, The Balancing of Interests in Free Speech Cases: In Defense of an Abused Doctrine, 2 LAW In Transition Q. 35, 52-53 (I965): "[U]ntil r956, the Court studiously refrained from any serious interference with government actions against alleged subversives." Mendelson, On the Meaning of the First Amendment: Absolutes in the Balance, 50 CaLIf. L. Rev. 82x, 828 (1962): "[T]he Supreme Court has not yet struck down a national measure on the basis of any provision in the first amendment." (The Lamont case, supra, decided in 1965 , is the very first exception.) Schenck v. United States, 249 U.S. 47, 52 (19r9): "When a nation is at war many things that might be said in time of peace are such $a$ hindrance to its effort that their utterance will not be endured so long as men fight and that no Court could regard them as protected by any constitutional right." Korematsu v. United States, 323 U.S. 2I4 (1944); Ex parte Quirin, 3I7 U.S. I (I942).

${ }^{19}$ Scales v. United States, 367 U.S. 203 (196r); Communist Party v. Subversive Activities Control Bd., 367 U.S. I (I96r); Barenblatt v. United States, 360 U.S. I09 (1959); Dennis v. United States, 34 I.S. 494 (I95I). See Frantz, The First Amendment in the Balance, 7I YaLE L.J. I424 (I962).

${ }^{50}$ See, e.g., Zemel v. Rusk, $38 \mathrm{I}$ U.S. I (1965); Banco Nacional de Cuba v. Sabbatino, 376 U.S. 398 (1964); Perez v. Brownell, 356 U.S. 44 (1958); United States v. Curtiss-Wright Export Corp., 299 U.S. 304 (1936); Henkin, The Treaty Makers and the Law Makers: The Law of the Land and Foreign Relations, I07 U. PA. L. REv. 903 (1959); Howard, Constitutional Limitations and American Foreign Policy, in Essays on the American Constitution 159 (Dietze ed. 1964).

${ }^{51}$ Yick Wo v. Hopkins, $x 18$ U.S. 356 (1886). See also Berger, Administrative Arbitrariness and Judicial Review, 65 Colum. L. Rev. 55 (1965); Comment, The Right to Non-discriminatory Enforcement of State Penal Laus, I6 Colum. L. REv. II03 (I96I).

${ }^{52}$ See note 48 supra.

${ }^{53}$ See Glendon A. Schubert, The Judicial Mind I43, 226 (I965).

${ }^{8}$ See Reich, Mr. Justice Black and the Living Constitution, 76 Harv. L. Rev. 673, 683 (1963).

${ }^{55}$ Professor Emerson recently reviewed four different first amendment "tests," Professor Kalven suggests that a fifth (associated with Professor Meiklejohn) has come to the fore, and I am certain that at least three of these five tests (clear and present danger, balancing, and absolute protection) can cach in turn be fractionated into three different tests, with the proponents of each variation quite able to find suitable judicial authority for support. For references and an illustration of the ups and downs of "clear and present danger," see note 56 infra.

56 The present condition (and content) of the clear-and-present-danger test remains in doubt, although the test still has considerable force. In Dennis v. United States, 34 I U.S. 494 (I95I), Chief Justice Vinson, writing for the Court, initially purported merely to apply the test as clarified by Judge Hand's "restatement." Clearly however, the test as applied by Vinson was not the same test in fact as applied by the Court during the previous two decades of its adoption, ten years after its first tentative statement 
by Holmes in Schenck v. United States, 249 U.S. 47 (19x9). See Loper, The Court of Chief Justice Hughes: Contribution to Civil Liberties, I3 Wayne L. Rev. 535, 572-95 (I966); Zechariah Chafee, FreE SPEECH IN THE UNITEd StATES 357-409 (I94I ed.). For a comprehensive listing of cases adverting to the test through 195I, see Justice Frankfurter's concurring opinion and Justice Douglas's dissenting opinion in Dennis, stupra, at 556-6r, 59r-92. In Dennis, the test as applied to federal antisedition laws was dropped to one of clear danger as reasonably determined by Congress, with a minimum of judicial review on the issue of congressional reasonableness and no requirement of imminency respecting the danger. The concurring opinions by Justices Frankfurter and Jackson clearly state the rationale for refusing to apply the Brandeis version [Whitney v. California, 274 U.S. 357, 377 (1927)] of the Holmes test. See also Justice Frankfurter's concurring opinion in Kovacs v. Cooper, 336 U.S. 77 (1949). Far from Dennis representing "at least a partial return to the Holmes-Brandeis version of the clear-and-presentdanger test," as suggested by Professor Newhouse, I believe that Dennis represented a temporary abandonment of the test. Emerson, Toward a General Theory of the First Amendment, 72 YALE L.J. 877 , 912 (1963): "The clear and present danger test was abandoned by a majority of the Supreme Court in the Dennis case." Indeed, Mr. Justice Frankfurter spent a good deal of his time in Dennis attempting to explain why it was impossible for the court even to entertain an independent judgment that the dangers meant to be curtailed by the Smith Act were "clear," rather than obscure, remote, and entirely problematical, and why it was that Congress would more or less be conclusively presumed to be reasonable in its determinations.

Still, Professor Kalven was not on safe ground in concluding that at least by 1964 , with New York Times Co. v. Sullivan, 376 U.S. 254 ( 1964 ), "it is clear that . . . [the clear-and-present-danger test] has disappeared." Kalven, The New York Times Case: A Note on "The Central Meaning of the First Amendment," I964 Sur. Cr. REv. 19I, 213-214. References in the Times case (376 U.S. at 273) to four leading applications of the clear-and-present-danger test [Bridges v. California, 3I4 U.S. 252 (I94I); Pennekamp v. Florida, 328 U.S. 33 I (I946); Craig v. Harney, 33I U.S. 367 (1947); Wood v. Georgia, 370 U.S. 375 (1962)] were applicable directly to the Times case itself. They tend to support the following propositions: (a) even a clear and present danger of mere injury to official reputation per se is not an evil within the power of government to avoid by suppressing speech; (b) the obstruction of justice is an avoidable evil, however, and it is imaginable that unrestrained defamation of public officials might obstruct justice by intimidating them from discharging their duties; $(c)$ but even an obstruction of justice may be avoided by abridging speech only when the speech in question constitutes a clear and present danger of precipitating the evil, and (d) police commissioners are presumed to be as hardy as judges and juries in their ability to withstand criticism without letting it interfere with their administration of justice; (e) moreover, there was no evidence in the Times case itself overcoming this presumption (i.e., no evidence of a clear and present danger that justice would be obstructed if plaintiff were unable to collect his $\$ 500,000$ judgment) and thus the law authorizing such a judgment under the circumstances violated the first amendment. The immediate sequel to Times, Garrison v. Louisiana, 379 U.S. 64 ( $(964)$, tended even more to recognize the continuing vitality of the clear-and-presentdanger test. See Karst, The First Amendment and Harry Kalven: An Appreciative Comment on the Advantages of Thinking Small, I3 U.C.L.A.L. REv. I, 7-9 (r965): "The announcement of that test's obliteration is surely premature." Id. at 9. It is quite true that the very next year, dicta in Cox v. Louisiana, 379 U.S. 559, 566 ( 1965$)$, misapplied the clear-and-present-danger test by standing the presumption of official hardiness on its head (i.e., the Court presumed that a large but peaceful demonstration in front of a courthouse inherently threatens the judicial process, or at least that a state legislature could reasonably conclude that this is so, in a narrowly-drawn statute), but even here, in dicta, the Court felt obliged to respect the test. See Kalven, The Concept of the Public Forum: Cox v. Louisiana, I965 SuP. CT. REv. I, 3r.

Again, in 1966, the Court employed the clear-and-present-danger test to dispatch a state statute affecting first amendment rights. Elfbrandt v. Russell, $3_{8}{ }_{4}$ U.S. II, I8 (Ig66): "A statute touching those protected rights must be 'narrowly drawn to define and punish specific conduct as constituting a clear and present danger to a substantial interest of the State." [Quoting Cantwell v. Connecticut, 3IO U.S. 296, 3 II (1940)]. For other post-Dennis uses of the test, see NAACP v. Button, 37I U.S. 4I5, 443. 453-54 ( $(\mathrm{Ig} 63)$; Edwards v. South Carolina, 272 U.S. 229, 244 ( $\mathrm{I} 963$ ); Wood v. Georgia, 370 U.S. 375 (1962). For standard criticisms that the clear-and-present-danger test simultaneously provides too much and too little protection, see Paur A. Freund, The Supreme Court of the United States 42-44 (ig6r); Alexander Meiklejohn, Polttical Freedom 29-50 (r960); Zechariah Chafee, Government AND Mass Communication 52-6r (I947); Emerson, Toward a General Theory of the First Amendment, 72 YALE L.J. 877, 910-I2 (1963); Howe, Book Review, 55 HARv. L. REv. 695 (1942); Wechsler, The Clear and Present Danger Test, 9 AM. L. Schoor Rev. 88I (I94I). 
out, ${ }^{57}$ has already surrendered on three previous occasions to the rationale that it has no place when the alleged evils of the speech in question are subliminal and where the danger is not of dramatic action the imminence of which can be estimated but of slow and corrosive demoralization yielding to the evil by degrees. On such a basis, the test had scarcely been accepted by a majority of the Court ${ }^{58}$ before it was partly discarded: first in the area of group libel, ${ }^{50}$ then for a time in the area of sedition, ${ }^{60}$ and still in the area of obscenity. ${ }^{61}$ Whether cases such as Lamont, Brown, Times, Yates, Aptheker, and Elfbrandt ${ }^{62}$ indicate that the Court has permanently abandoned the self-abnegation of Gitlow, Beauharnais, and Dennis ${ }^{63}$ (all of which Professors Whitton and Larson exclusively relied upon) remains to be seen. The unsatisfactory state of the first amendment in the field of obscenity, as continued through Ginzburg, ${ }^{64}$ is not a reassuring sign.

Finally, it should be noted that the conflict between the orientation of international law norms as described by Professors Whitton and Larson and the orientation of our own political process may be even deeper than noted in Professor Newhouse's very excellent paper. The assumption of the Whitton-Larson book seems to be not only that certain governmental decisions are forbidden to a nation but that certain forms of speech which may tend to bring about such decisions by any means are equally forbidden to its people. The burden of the book has been in part to demonstrate that each government has an affirmative obligation to suppress international tension producing propaganda whether or not that propaganda is internal, private, and part of a continuing political debate. If the tendency of that debate is to generate

\footnotetext{
${ }^{57}$ Harry Kalven, JR., The Negro and the First Amendment $12-52$.

${ }^{88}$ See note 56 supra.

${ }^{50}$ Compare Beauharnais v. Illinois, 343 U.S. 250 (1952), with New York Times Co. v. Sullivan, 376 U.S. $254(1964)$.

${ }^{\circ 0}$ Compare Dennis v. United States, 34 I.S. 494 (195I), with Elfbrandt v. Russell, 384 U.S. II (Ig66).

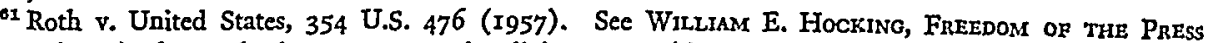
I92-93 (1947), for a classic statement rationalizing censorship, never stopping to examine its rife presumptions. See also Walter Berns, Freedom, Virtue and the First Amendment (1957). C $f$. H. L. A. HART, LAW, LiberTy AND MoraIITY ( 1963 ). The Court took a turn away from Plato in Kingsley Int'l Pictures Corp. v. Regents, 360 U.S. 684 (1959). Mr. Justice Rutledge once described the dilemma presented by attempts to curb the advocacy of "immoral conduct," in Musser v. Utah, 333 U.S. 95, I0I-102 (1948) (dissenting opinion), as follows:

"It is axiomatic that a democratic state may not deny its citizens the right to criticize existing laws and to urge that they be changed. And yet, in order to succeed in an effort to legalize polygamy it is obviously necessary to convince a substantial number of people that such conduct is desirable. But conviction that the practice is desirable has a natural tendency to induce the practice itself. Thus, depending on where the circular reasoning is started, the advocacy of polygamy may either be unlawful as inducing a violation of law, or be constitutionally protected as essential to the proper functioning of the democratic process."

${ }^{62}$ Lamont v. Postmaster General, $38 \mathrm{I}$ U.S. $30 \mathrm{x}$ (1965); United States v. Brown, 38I U.S. 437 (1965); New York Times Co. v. Sullivan, 376 U.S. 254 (1964); Yates v. United States, 354 U.S. 298 (r957); Aptheker v. Secretary of State, 378 U.S. 500 (1964); Elfbrandt v. Russell, 384 U.S. Ir (1966). ${ }^{03}$ Gitlow v. New York, 268 U.S. 652 (1925); Beauharnais v. Illinois, 343 U.S. 250 (1952); Dennis v. United States, 34I U.S. 494 (I95I).

o< Ginzburg v. United States, 383 U.S. 463 (I966).
} 
sufficient force within the country so that a change in government policy committing that country to an aggressive war were made imminent by the trend of the debate itself, for instance, the existing government would have the duty as well as power to cut off the debate to avoid the change in policy which might otherwise ensue. ${ }^{65}$ The duty to arrest interior warmongering propaganda before it can succeed in effecting a change in the external policies of the government is implicit in the government's larger duty to avoid the aggressive war which would become inevitable with the change in policy.

Unless Missouri v. Holland $d^{86}$ were to be radically extended or the Constitution amended, however, I foresee no way in which the government of the United States could conscientiously and correctly bind itself even by treaty to the suppression of interior warmongering propaganda which directs its appeal to the democratic process and is simply an integral part of a ceaseless debate over public policy. ${ }^{67}$ At least this is so to the extent that the enforcement of sanctions would be reviewable in our own Supreme Court and as long as the Court may be true to the spirit of Times.

It would not be enough that the propaganda would pose a clear and present danger of bringing about the "evil" change in policy. Nor would it be enough that the propaganda, discounted by the improbability of its effectuating such a policy change, would still be highly likely to succeed unless the propaganda could be stopped. The plain fact of the matter is that the mode of accomplishing the change is constitutionally protected and that the change cannot be resisted by government if it is sought to be accomplished by means of the protected mode.

The ulterior evil may be aggressive war, but the means employed, by hypothesis, are only those of working within and through the democratic process immediately to effect a change of a governmental policy which is always within the power of the people ultimately to determine for themselves. The Constitution grants to Congress the power to declare war, ${ }^{68}$ a power not couched in terms of wars of self-defense or limited to wars which may be authorized by international law. Within our own system the first amendment guarantees each individual the right to urge his government to exercise that power or to join with others peacefully to press for the election of a Congress which will exercise that power, as much as though that individual had called for congressional action under the commerce clause or any other clause. So long as one's speech is employed simply to petition his government to act, or to

OS The power of the United States government to suppress private warmongering propaganda posing a clear and present danger of success is defended in Whrtron \& LARson 233-40. The international law duty of governments not to engage in warmongering propaganda is reviewed. Id. at 62-82. The authors conclude (id. at $156-66$ ) that there is no clearly established international law duty requiring a state to suppress private warmongering propaganda but that such a duty does arise by treaty, and that there is a general international duty to suppress propaganda imminently likely to produce a hostile expedition from within the country.

${ }^{60} 252$ U.S. 4 I6 (I920).

-7 But see Garcín-Mora, op. cit. supra note 3I, at 88-89.

${ }^{\circ 8}$ U.S. Const. art. I, $\$ 8$. 
incite others to join him in voting for men who will act, he could not be punished without abandonment of the first amendment. ${ }^{69}$

Should it make any difference in the outcome if Congress were first to renounce the aggressive war power (as arguably it has done by subscribing to the Charter of the United Nations $)^{70}$ before it outlawed warmongering propaganda? Probably not. It is doubtful, first of all, that Congress may completely relinquish by treaty or by any other means a power granted it by the Constitution. But even assuming that a given Congress could at least strip itself of its delegated powers (and not merely forbear exercising such powers) without constitutional amendment, could it also go forward to punish speech inciting people to press Congress to declare war anyway, or inciting them to elect a Congress and a President to abrogate the treaty, reclaim their power, and immediately thereafter declare war? The effect of the treaty, the validity of its abrogation, and the constitutionality of the decision to declare war possibly might (but probably would not) present justiciable issues for review in the Supreme Court, but speech which merely calls upon Congress to take action which the Court may hold to be beyond its power on some judicial occasion of its testing can scarcely be forbidden on that account.

The same answer almost surely applies to other forms of warmongering propaganda in the ceaseless debate of public policy. Could a candidate for office be punished for offering the view that the national salvation lay in drastic action to establish a Pax Americana under a global empire established by conquest and for urging his own election with the promise that he would bend every effort in office to that end? Does the answer depend to any degree upon how clear and present the danger that, unless stopped, the candidate and others like him will be elected? Any

\footnotetext{
${ }^{\circ}$ Dennis v. United States, 34I U.S. 494, 575 (I95I) (concurring opinion): "I do not suggest that Congress could puinish conspiracy to advocate something, the doing of which it may not punish."

${ }_{70}$ The Charter of the United Nations, to which the United States is a signatory, 59 Stat. I031 (1945), provides in article 2, paragraph 4 :

All Members shall refrain in their international relations from the threat or use of force against the territorial integrity or political independence of any state, or in any other manner inconsistent with the Purposes of the United Nations.

Without referring to specific sections of the Charter, various officials of the United States goverament have stated that acts of aggressive force are outlawed under the Charter. See, e.g., IAN BrownLIE, INTERnational LaW and the Use of Force by States ilg (1963); 5 Marjorie M. Whiteman, Digest of INTERNATIONAL LAW 778-80 ( 1963 ). Article 2, paragraph 4, quoted above, must of course be considered in light of Article $5 \mathrm{I}$, which provides:

Nothing in the present Charter shall impair the inherent right of individual or collective self-defense if an armed attack occurs against a Member of the United Nations, until the Security Council has taken measures necessary to maintain international peace and security. Measures taken by Members in the exercise of this right of self-defense shall be immediately reported to the Security Council and shall not in any way affect the authority and responsibility of the Security Council under the present Charter to take at any time such action as it deems necessary in order to maintain or restore international peace and security.

On various occasions the renunciation of aggressive force or threat has conflicted with the claimed right of self-defense. See Brownure, op. cit. sitpra, at 264-80. An alleged conflict is evidenced today in the Vietnam engagement. Compare 54 Dep'T StaTe Bull. 474 (1966), with Memorandum of Latu by Lawyers' Committee on American Policy Towards Vietnam, reprinted in III Cong. REc. 24011-I8 (daily ed. Sept. 23, 1965 ).
} 
more, say, than a candidate in a southern community could be stopped from urging his own election with the promise that he would bend every effort to re-establish segregation? Or than a citizen could be stopped from vocally supporting the election of a candidate pledged to the establishment of a state religion? The answer, barring only the kind of judicial oversight which occurred in Beauharnais, ${ }^{71}$ seems to me to be a clear and obvious "no." 72

The point of this exercise is equally obvious, but I have ventured its restatement to bring us back to realism in dealing with the capacity of our system as it presently exists to curtail the more serious forms of warmongering propaganda. In their book, Professors Whitton and Larson advert to the following statute adopted in I794, and still in effect, as an illustration of useful and constitutional legislation: $:^{73}$

Whoever, within the United States, knowingly begins or sets on foot or provides or prepares a means for or furnishes the money for, or takes part in, any military or naval expedition or enterprise to be carried on from thence against the territory or dominion of any foreign prince or state, or of any colony, district, or people with whom the United States is at peace, shall be fined not more than $\$ 3,000$ or imprisoned for not more than three years, or both. ${ }^{74}$

They also develop the suggestion that "incipient steps" toward the support of such forbidden enterprises, including "the use of words to plan, organize, equip, finance, transport or in other tangible ways forward the forbidden venture," may be forbidden by the statute. ${ }^{75}$ They may well be right, but we need to note that this statute of I794 necessarily reaches only such speech as may be directed at private action taken outside the processes of government to mount a private venture or war effort in conflict with current policy, rather than speech designed to change the policy itself. Warmongering propaganda within the United States posing the more substantial threat today, however, is doubtless directed to move the government itself to take arms against a sea of troubles. The "really dangerous" appeal from the private sector is that the Congress should act, that the President should act, or, failing that, that the people should act to replace them with more determined men. The cases adjudicating the statute of $\mathrm{x} 794$ provide no precedent at all that exhortations of this latter kind can constitutionally be arrested. This more substantial

\footnotetext{
${ }^{71} 343$ U.S. 250 (1952). See Harry Kalven, JR., The Negro and the First Amendment 7-64 $(1964)$.

${ }_{73}$ The point that, until amended, the Constitution through its first amendment protects utterances clearly and presently likely to succeed through the democratic process itself is illustrated in the.dictum of Mr. Justice Holmes: "If in the long run the beliefs expressed in proletarian dictatorship are destined to be accepted by the dominant forces of the community, the only meaning of free speech is that they should be given their chance and have their way." Gitlow v. New York, 268 U.S. 652, 673 (I925) (dissenting opinion). See also all of note 5 supra.

${ }^{73}$ WHITTON \& LARSON 238.

74 I8 U.S.C. $\$ 960$ ( 1964$)$. For a brief presentation of the legislative development of this statute from 1794 to 1962 and the judicial construction at various stages of its evolution, see García-MorA, op. cit. supra note 3I, at 53-58, 86; 7 G. H. Hackworth, Digest of INTERNational LaW 396-404 (1943). ${ }^{30}$ WhitToN \& LaRson 239.
} 
threat not only is not reached by any federal statute, it cannot be reached by any statute consistent with the first amendment.

I cannot agree, therefore, that there are no substantial constitutional issues which hedge the power of government significantly to curtail warmongering propaganda within the United States, to control the domestic consumption of subversive or defamatory propaganda sent from abroad, or even to silence its own officialdom. Beyond that, I despair of attempts to legislate virtuous speech in debates of public policy, and I doubt whether the politics of government will permit the merely neutral application of antipropaganda laws. The possibility of a truly catastrophic war casts a pall over everything else, and it is doubtless made greater by the free circulation of malevolent propaganda. Much that Professors Whitton and Larson have written shows well that this is so, and their suggestions for the curtailment of propaganda across national lines are both sobering and excellent. How well their other suggestions can carry within the United States, where even a choice of national suicide is constitutionally a right of the people if exercised in a certain way, may be more doubtful. 